\title{
Analysis of Business Performance
}

\section{in the Case of Mixed Farm}

\author{
Karmen Pažek (Corresponding author) and Darja Majkovič \\ Dep. of Agricultural Economics and Rural Development \\ Faculty of Agriculture and Life Sciences Maribor \\ Pivola 10, 2311 Hoce, Slovenia
}

Tel: 386-223-0900Ｅ-mail: karmen.pazek@uni-mb.si,darja.majkovic@uni-mb.si

\section{Jožef Vinčec}

Gancani 15a, 9231 Beltinci, Slovenia

E-mail: jozef.vincec@gmail.com

\begin{abstract}
The economic analysis of business process on the mixed farm in Prekmurje region in Slovenia was performed. For the assessment of farm business analysis specific technologic-economic simulation model with sub-models were developed. The analysis showed that the most economically feasible vegetable product is onion (Financial result, $\mathrm{FR}=2783.71 €$ and Coefficient of economics, $\mathrm{Ce}=2.24)$. Among the analyzed field crops is economically the most interesting production of oil pumpkins $(\mathrm{FR}=1920.84 €$ and $\mathrm{Ce}=$ 2.13). The analysis showed that the production of analyzed crops without direct payments is economically unfeasible. Further, linear optimization program for optimization farm production plan was presented too. Considering financial results maximization, production total cost minimization, as well as other resource limitation, in the production plan, the most advantageous combination is one of barley and oilseed rape by the scenario 1 . In scenario 2 , early cabbage, onion and early potatoes production were suggested. By the scenario 3 barley, red onions, and silver onions is defined. By the last scenario 4 onions and pumpkin oil production is suggested.
\end{abstract}

Keywords: Economics, Simulation models, Optimization process, Vegetable farm 


\section{Introduction}

Agricultural production is in recent years facing many problems which directly or indirectly affect the prices on the market, which has significant impact on farm operations. Agricultural production may be partly planned in line with trends of average earnings over the last or past years, assuming that the farm output depends on the ability of farm production in the prescribed time period, the available surface, and especially the performance of production in the past year, which is assessed by using indicators of economic viability.

In analyzing the farm business it is important to analyze the assortment of products, and thus it was necessary to observe a number of factors. The analysis should not focus only on the sales aspect, but also on aspects of other activities and functions on the farm. Focus on several aspects of the business brings us to the question of what to produce or offer to the market by serving the market needs. Therefore it is necessary to know farm production capacity and capability to produce with the largest financial result possible. Information is an essential element in the adoption of new business decisions (Kay et al., 2004). In this process the accuracy of data entry is vital for further work in analyzing the results of our production. In the last few decades, the agricultural decision makers have get accustomed to the use of computers and consequently to the implementation of different complex computer models for solution of various planning problems. This includes decision problems and agricultural project solutions, which have long been predominated by different types of simulation models (Rozman et al., 2002; Pavlovič, 1997). However, experiences described in literature (Hester and Cacho (2003), Recio et al. (2003), De Toro and Hansson (2003), Lisson et al. (2003), Romera et al. (2003) and Herrero et al. (1999)) emphasise that a variety of agricultural problems can be solved with computer modelling and simulation process. In this context the methodology of an integrated deterministic simulation system application for decision-making support on organic farms is described by Pažek et al. (2006). Further Berbel (1989) deals with labour managed horticultural firms in Southeastern Spain. It tries to model the decision-making processes and the conflicts between profit maximization, risk minimization, leisure and seasonal labour as decision makers' objectives. Further Hardaker and Pandey (1991) presented the complexity of modelling risk in farming systems with emphasis on stochastic efficiency criteria for analysis of systems when risk preferences of individual farmers are unavailable. Fully integrated and interactive elicitation-optimization procedure for portfolio management was presented by Duval and Featherstone (2002). Methodology for the analysis of input use in the agricultural sector was presented by Gómez-Limón et al. (2004). The novelty of the theoretical model is described by Juan et al. (1996). The authors presented the application of multi-criteria environment ("multi-attribute utility" and "multi-attribute marginal utility") in the case of water for irrigation.

With the goal to make the most of limited resources, engaged in farm and profit maximization, we analyze the performance of the farm. By model calculations of agricultural production and associated sub-models the production of respective culture was first analyzed. Results obtained from model calculations of agricultural production were then used in the mathematical model of linear programming, where we seek the optimal structure of sowing or planting crops. 
This article is constructed in the following order: in the first part we present the methodology and theoretical background. The second part presents an actual example of the use of models in practice (such as business analysis on the farm) and concluded with the interpretations of the results.

\section{Methodology}

The computer simulation model as a decision support tool for the decision maker (i.e. farmer) was developed for the economical analysis of the farm production and in observed Slovene Prekmurje region). Individual production model consists of calculating the most important economic and parameters. After all necessary technologic and some economic input parameters (yield quantity, fertilizer, prices, human and machine labour, etc.) have been put into the developed model it estimates individual production technical parameters, production costs, annual cash-flows and ultimately the Coefficient of economics. The technical relationships in the system are expressed with a set of equations or with corresponding functional relationships. However, to analyze and chose the most suitable farm product and its combination in crop rotation two main methods were used through simulation modeling and linear programming.

Simulation modeling is a way of solving problems with the method of experimentation with the computer model in order to analyze the functioning of the whole or individual parts of the system in certain conditions.

In addition to the basic model we develop following sub-models:

- Irrigation calculation

- Machines calculation

Sub-irrigation reckon model is a model that allows us to determine the number of hours and provides us the required amount from any plant within a specified period required for the continued growth and development. The model is partially extracted from the Pintar study (2003). However, it was upgraded by adding the possibility of real-time monitoring of rainfall, irrigation, which allows us more realistic irrigation

Sub - model for machines calculation is adapted from machinery catalog costs (Dolenšek, 2008), which granted each year for the union of associations, neighborhood assistance hardware platforms Slovenia.

Sub-model for machines calculations were upgraded in the way that we capture:

- Annual use - the number of tractor and other hours is adapted to the actual situation on the farm.

- Costs of tractor and other machinery were equal to the real situation on the farm.

Both sub-models represent the base for the main model for the calculations for agricultural production, which allows us evaluation of various indicators in following scenarios:

- Planned scenarios:

o Without direct payments. 
o With direct payments included.

- Real scenarios:

o Without direct payments.

o With included direct payments.

The simulation model allows the monitoring of planned and realized production by the following formulas:

- $\quad$ Yield $=$ reached yield at area / planned yield at area

- $\quad$ Revenue $=$ reached revenue at area / planned revenue at area

- Revenue with included direct payments = reached revenue with included direct payments / planned revenue at area with included direct payments

In our research following economic indicators were used, with some of these formulas being modified and used in our simulation model:

Table 1. Formulas for calculation financial results

\begin{tabular}{|l|c|l|c|}
\hline \multicolumn{2}{|c|}{ PLANNED RESULTS } & \multicolumn{2}{c|}{ REACHED RESULTS } \\
\hline $\begin{array}{c}\text { Included direct } \\
\text { payments }\end{array}$ & $\begin{array}{c}\text { Without direct } \\
\text { payments }\end{array}$ & $\begin{array}{c}\text { Included direct } \\
\text { payments }\end{array}$ & $\begin{array}{c}\text { Without direct } \\
\text { payments }\end{array}$ \\
\hline $\mathbf{F R}=\mathbf{V P p}-\mathbf{( T C}-\mathbf{D P})$ & $\mathbf{F R}=\mathbf{V P p}-\mathbf{T C}$ & $\mathbf{F R}=\mathbf{V P r}-\mathbf{T C}-\mathbf{D P})$ & $\mathbf{F R}=\mathbf{V P r}-\mathbf{T C}$ \\
\hline $\mathrm{FR}=$ financial results & $\mathrm{FR}=$ financial results \\
\hline $\mathrm{VPp}=$ planned value of production & $\mathrm{VPr}=$ reached value of production \\
\hline $\mathrm{DP}=$ value of direct payments & $\mathrm{TC}=$ total costs \\
\hline
\end{tabular}

Table 2. Formulas for calculation value of production

\begin{tabular}{|c|c|c|c|}
\hline \multicolumn{2}{|c|}{ PLANNED RESULTS } & \multicolumn{2}{|c|}{ REACHED RESULTS } \\
\hline $\begin{array}{l}\text { Included direct } \\
\text { payments }\end{array}$ & $\begin{array}{l}\text { Without direct } \\
\text { payments }\end{array}$ & $\begin{array}{l}\text { Included direct } \\
\text { payments }\end{array}$ & $\begin{array}{l}\text { Without direct } \\
\text { payments }\end{array}$ \\
\hline \multicolumn{2}{|c|}{ 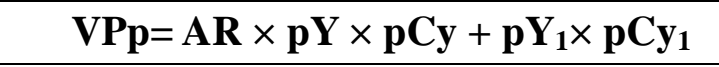 } & VPrd $=\mathbf{r I D P}$ & $\mathbf{V P r}=\mathbf{r I}$ \\
\hline \multicolumn{2}{|c|}{$\mathrm{VPp}=$ planned value of production } & \multicolumn{2}{|c|}{$\begin{array}{l}\text { VPrd }=\text { reached value of production at area } \\
\text { with included direct payments }\end{array}$} \\
\hline \multicolumn{2}{|l|}{$\mathrm{AR}=$ area in ha; } & \multicolumn{2}{|c|}{$\begin{array}{l}\text { rIDP }=\text { reached income at the area with } \\
\text { included direct payments }\end{array}$} \\
\hline \multicolumn{2}{|c|}{$\mathrm{pY}=$ planned quantity of yield } & \multicolumn{2}{|c|}{$\mathrm{VPr}=$ reached value of production at area } \\
\hline \multicolumn{2}{|c|}{$\mathrm{pY}_{1}=$ planned quantity of side yield } & \multirow{2}{*}{\multicolumn{2}{|c|}{$\begin{array}{l}\mathrm{rI}=\text { reached income at the area without direc } \\
\text { payments }\end{array}$}} \\
\hline \multicolumn{2}{|c|}{$\mathrm{pCy}=$ planned price of product per unit } & & \\
\hline \multicolumn{2}{|c|}{$\mathrm{pCy}_{1}=$ planned price of side product per unit } & & \\
\hline
\end{tabular}


Table 3. Formulas for calculation cost price

\begin{tabular}{|l|c|l|c|}
\hline \multicolumn{2}{|c|}{ PLANNED RESULTS } & \multicolumn{2}{c|}{ REACHED RESULTS } \\
\hline $\begin{array}{c}\text { Included direct } \\
\text { payments }\end{array}$ & $\begin{array}{c}\text { Without direct } \\
\text { payments }\end{array}$ & $\begin{array}{c}\text { Included direct } \\
\text { payments }\end{array}$ & $\begin{array}{c}\text { Without direct } \\
\text { payments }\end{array}$ \\
\hline $\mathbf{C P}=\mathbf{T C}-\mathbf{D P} / \mathbf{p Y}$ & $\mathbf{C P}=\mathbf{T C} / \mathbf{Y}$ & $\mathbf{C P}=\mathbf{T C}-\mathbf{D P} / \mathbf{d Y}$ & $\mathbf{C P}=\mathbf{T C} / \mathbf{d Y}$ \\
\hline $\mathrm{CP}=$ cost price & $\mathrm{CP}=$ cost price \\
\hline $\mathrm{TC}=$ total costs & $\mathrm{DP}=$ value of direct payments \\
\hline $\mathrm{pY}=$ planned quantity of yield & $\mathrm{dY}=$ reached quantity of yield \\
\hline
\end{tabular}

Table 4. Formulas for calculation coefficient of economy

\begin{tabular}{|l|c|c|c|}
\hline \multicolumn{2}{|c|}{ PLANNED RESULTS } & \multicolumn{2}{c|}{ REACHED RESULTS } \\
\hline $\begin{array}{c}\text { Included direct } \\
\text { payments }\end{array}$ & $\begin{array}{c}\text { Without direct } \\
\text { payments }\end{array}$ & $\begin{array}{c}\text { Included direct } \\
\text { payments }\end{array}$ & $\begin{array}{c}\text { Without direct } \\
\text { payments }\end{array}$ \\
\hline $\mathbf{C e}=\mathbf{V P p} / \mathbf{T C}-\mathrm{DP}$ & $\mathbf{C e}=\mathbf{V P p} / \mathbf{T C}$ & $\mathbf{C e}=\mathbf{V P r} / \mathbf{T C}-\mathrm{DP}$ & $\mathbf{C e}=\mathbf{V P r} / \mathbf{T C}$ \\
\hline $\mathrm{Ce}=$ coefficient of economy & $\mathrm{Ce}=$ coefficient of economy \\
\hline $\mathrm{VPp}=$ planned value of production & $\mathrm{VPR}=$ reached value of production \\
\hline $\mathrm{TC}=$ total costs & $\mathrm{DP}=$ value of direct payments \\
\hline
\end{tabular}

Table 5. Formulas for calculation breaking point of production

\begin{tabular}{|l|l|l|l|}
\hline \multicolumn{2}{|c|}{ PLANNED RESULTS } & \multicolumn{2}{c|}{ REACHED RESULTS } \\
\hline $\begin{array}{c}\text { Included direct } \\
\text { payments }\end{array}$ & $\begin{array}{c}\text { Without direct } \\
\text { payments }\end{array}$ & Included direct payments & $\begin{array}{c}\text { Without direct } \\
\text { payments }\end{array}$ \\
\hline BPP=TC-DP/Cy & $\mathbf{B P P}=\mathbf{T C} / \mathbf{C y}$ & $\mathbf{B P P}=(\mathbf{T C}-\mathbf{D P}) /(\mathbf{r I D P} / \mathbf{d Y})$ & $\mathbf{B P P}=\mathbf{T C} /(\mathbf{r I} / \mathbf{d Y})$ \\
\hline $\mathrm{BPP}=$ breaking point of production & $\mathrm{BPP}=$ breaking point of production \\
\hline TC = total costs & $\begin{array}{l}\text { rIDP= reached income at the area with included } \\
\text { direct payments }\end{array}$ \\
\hline $\mathrm{DP}=$ value of direct payments & $\mathrm{dY}=$ reached quantity of yield \\
\hline $\mathrm{Cy}-$ price of product per unit & $\mathrm{rI=}$ reached income \\
\hline
\end{tabular}

Mathematical formulation of linear program used is:

- Maximal financial results

$\mathrm{FR} \max =\mathrm{x} 1 * \mathrm{FR} 1+\mathrm{x} 2 * \mathrm{FR} 2+\mathrm{x} 3 * \mathrm{FR} 3+\mathrm{x} 4 * \mathrm{FR} 4+\ldots+\mathrm{xb} * \mathrm{FRb}$

Where:

$\mathrm{FR} 1 \ldots \mathrm{FRb}$

Financial results of selective crop 
$\mathrm{x} 1 \ldots \mathrm{xb}$

Area of production (ha)

- Machine working hours:

$\mathrm{a} 1 * \mathrm{x} 1+\ldots \mathrm{an} * \mathrm{xb}<=\mathrm{s} 1-$ psdun

Where is:

a1...ab Number of available monthly machine working hours

s1 Available machine working hours per month

Psdun Used machine working hours per month

$\mathrm{N} \quad$ Number of months $(\mathrm{n}=12)$

- Human working hours

$\mathrm{b} 1 * \mathrm{x} 1+\ldots \mathrm{br} * \mathrm{xb}<=\mathrm{r} 1-$ prdub

Where is:
b1...bb
Number of available monthly human working hours
r1
Available human working hours per month
prdub
Used human working hours per month

\section{Results}

In the article an example of calculation simulation model use is presented in the case of onion production. In the beginning we also show how we used the data from simulation model in the linear model program for the optimization of agricultural production.

Onion was grown up on the surface of $0.62 \mathrm{ha}$, where $23740 \mathrm{~kg}$ of onion was produced, (average yield of $38290 \mathrm{~kg} / \mathrm{ha}$ ). Average selling price per kilogram of onion was $0.20 € / \mathrm{kg}$, which mean $4814 €$ of income at the area of production without direct payments and the 5 $035.69 €$ with included direct payments (which in this case reach $357.11 € / \mathrm{ha}$ ).

Table 6. Planned and reached results for used economic indicators in onion ( $0.62 \mathrm{ha})$

\begin{tabular}{|c|c|c|c|c|}
\hline \multicolumn{3}{|c|}{ PLANNED RESULTS } & \multicolumn{2}{|c|}{ REACHED RESULTS } \\
\hline Onion & $\begin{array}{l}\text { Without direct } \\
\text { payments }\end{array}$ & $\begin{array}{l}\text { Included direct } \\
\text { payments }\end{array}$ & $\begin{array}{l}\text { Without direct } \\
\text { payments }\end{array}$ & $\begin{array}{l}\text { Included direct } \\
\text { payments }\end{array}$ \\
\hline $\mathbf{C P}$ & 0.07 & 0.07 & 0.09 & 0.09 \\
\hline VP & 6421.41 & 6200.00 & 5035.70 & 4814.29 \\
\hline FR & 4169.42 & 3948.01 & 2783.71 & 2562.30 \\
\hline CE & 2.85 & 2.75 & 2.24 & 2.14 \\
\hline BPP & 10152.91 & 11259.95 & 9572.86 & 11104.91 \\
\hline
\end{tabular}

Cost price of onion with included direct payments is $0.09 € / \mathrm{kg}$. Cost price in spite of lower planned quantity of crop separates in small share. With included direct payments cost price is $0.07 € / \mathrm{kg}$.

Financial result of a produced onion with included direct payments is $2783.71 €$, and without direct payments it lowers to $2562.30 €$. 
Production of an onion with included direct payments is economically viable, which is also confirmed by coefficient of economy (2.24). Without direct payments coefficient of economy is 2.14. In scenario with planed quantity of yield, this is higher than our reached coefficient of economy reached 2.85 or without included direct payments are 2.75 .

In the beginning of our research we use collected data from simulation model and used in mathematical linear model program, where we predicted 4 different scenarios:

\subsection{Scenario 1}

First scenario includes: corn, oilseed rape, barley and fodder pea

Table 7. Limits of optimization (Scenario 1)

\begin{tabular}{|l|r|}
\hline available number of tractor hours & 500 \\
\hline available number of human working hours & 1000 \\
\hline available area (ha) & 10 \\
\hline
\end{tabular}

Table 8. Results of optimization problem (Scenario 1)

\begin{tabular}{|l|c|c|c|c|c|}
\hline & Corn & Oilseed rape & Barley & Fodder pea & Total \\
\hline Max FR & 46.03 & 5.29 & 299.70 & -143.33 & 1676.15 \\
\hline Solution area & 0.00 & 2.77 & 7.23 & 0.00 & 10.00 \\
\hline
\end{tabular}

Results indicate that the best combination is sowing of oilseed rape (2.77 ha) and barley ( 7.23 ha).

\subsection{Scenario 2}

Second scenario includes: early cabbage, onions, early potatoes and silver onion.

Table 9. Limits of optimization (Scenario 2)

\begin{tabular}{|l|r|}
\hline Available number of tractor hours & 800 \\
\hline Available number of human working hours & 5000 \\
\hline Available area (ha) & 10 \\
\hline
\end{tabular}

Table 10. Results of optimization problem (Scenario 2)

\begin{tabular}{|l|c|l|c|c|c|}
\hline & Early cabbage & Onion & Early potatoes & Silver onion & Total \\
\hline Max FR & 1092.96 & 2783.71 & 871.65 & 322.71 & 17648.84 \\
\hline Solution area & 1.09 & 5.55 & 1.12 & 0.00 & 10.00 \\
\hline
\end{tabular}

Results indicate that the best combination is sowing of onion 5.55 ha, early potatoes 1.12 ha an early cabbage 1.09 ha.

\subsection{Scenario 3}

Third scenario includes: barley, red onion, silver onion and corn. 
Table 11. Limits of optimization (Scenario 3)

\begin{tabular}{|l|r|}
\hline Available number of tractor hours & 1000 \\
\hline Available number of human working hours & 2000 \\
\hline Available area (ha) & 10 \\
\hline
\end{tabular}

Table 12. Results of optimization problem (Scenario 3)

\begin{tabular}{|l|c|c|c|c|c|}
\hline & Barley & Red onion & Silver onion & Corn & Total \\
\hline Max FR & 229.67 & 271.67 & 322.71 & 46.03 & 2533.39 \\
\hline Solution area & 6.26 & 2.18 & 1.56 & 0.00 & 10.00 \\
\hline
\end{tabular}

Results indicate that the best combination is sowing of barley 6.26 ha, red onion 2.18 ha and silver onion 1.56 ha.

\subsection{Scenario 4}

Fourth scenario includes: early cabbage, onion, early potatoes and oil pumpkins

Table 13. Limits of optimization (Scenario 4)

\begin{tabular}{|l|r|}
\hline Available number of tractor hours & 1000 \\
\hline Available number of human working hours & 5000 \\
\hline Available area (ha) & 10 \\
\hline
\end{tabular}

Table 14. Results of optimization problem (Scenario 4)

\begin{tabular}{|l|c|c|c|c|c|}
\hline & Early cabbage & Onion & Early potatoes & Oil pumpkins & Total \\
\hline Max FR & 1092.96 & 2783.71 & 871.65 & 1920.84 & 2533.39 \\
\hline Solution area & 0.00 & 5.49 & 0.00 & 4.54 & 10.00 \\
\hline
\end{tabular}

Results indicate that the best combination is sowing of onion 5.49 ha and oil pumpkins 4.54 ha.

We predict four different scenarios of the optimization agricultural production plan. The results obtained that, the first and fourth scenario show the solution for only 2 of 4 growing plant, while third and the second scenario, show the solution for 3 growing plant of 4 .

For use in practice, the solution for a given scenario should include all four plants assumed, to satisfy the basic requirements of crop rotation, prescribed in the system of integrated production of vegetables and crops in analyzed production system. For the optimal solution in the future it would be necessary to streamline its FR or human working hours and tractor working hours.

\section{Conclusion}

For successful planning of future production it is necessary first to calculate the performance of production and respective agricultural cultures, to develop a simulation model of agricultural production reckoning, using sub-models. The model calculates enables calculation of major economic indicators which show the economic efficiency of production, 
and the financial result as the basis for finding the optimal structure or sowing. The results show that vegetable production is economically more justified than the crops. Regarding direct payments as the policy instrument of CAP (Common Agricultural Policy), crop production on the farm without direct payments is economically not justifiable, and on the contrary, the production of vegetables without direct payments viable. The results of the optimization of the production at the farm show that the first scenario yields with most favorable structure of sowing barley and oilseed rape; by the second scenario early cabbage, onion and early potatoes; by the 3rd scenario are barley, red onions, black onions and fourth scenario sets onions and pumpkin oil as most favorable in terms of economical performance of the farm.

\section{References}

Berbel, J. (1989). Analysis of protected cropping: an application of multi-objective programming techniques to Spanish horticulture. European Review of Agricultural Economics, 16, pp.203-216.

De Toro, A., \& Hansson, P.A. (2003). Analysis of field machinery performance based on daily soil workability status using discrete event simulation or on average workday probability. Agricultural Systems, 79, pp.109-129.

Dolenšek, M. (2008). Katalog strojev kmetijske mehanizacije: Zveza združenj za medsosedsko pomoč strojnih krožkov Slovenije.

Duval, Y., \& Featherstone, A. M. (2002). Interactivity and Soft Computing in Portfolio Management: Should Farmers Own Food and Agribusiness Stocks? American Journal of Agricultural Economics, 84(1), pp.120-133.

Gómez-Limón, J. A., Riesgo, L., \& Arriaza, M. (2004). Multi-Criteria analysis of input use in agriculture. Journal of Agricultural Economics, 55(3), pp.541-564.

Hardaker, J. B, \& Pandey, S. (1991). Farm planning under uncertainty: A review of alternative programming models. Review of Marketing and Agricultural Economics, 59, pp. 9-22.

Herrero, M., Fawcett, R.H., \& Dent, J.B. (1999). Bio-economic evaluation of dairy farm management scenarios using integrated simulation and multiple-objectives models. Agricultural Systems, 69, pp.169-188.

Hester, M. S., \& Cacho, O. (2003). Modelling apple orchard systems. Agricultural Systems, 77, pp.137-154.

Juan, J. A., Trajuelo, J. M., Valiente, M., \& Garcia P. (1996). Model for cropping patterns within the farm based on crop water production functions and irrigation uniformity I: development decision model. Agricultural Water Management, 31, pp.115-143.

Kay, R. D., Edwards, W. M., \& Duffy, P. A. (2004). Farm management. pp.9-36.

Lisson, S. N., Brennan, L. E., Bristow, K. L., Keating, B. A \& Hughes, D. A. (2003). DAM 
EA\$Y- Software for assessing the costs and benefits of on farm water storage based production systems. Agricultural Systems, 76, pp.19-38.

Pavlovič, M. (1997). Systemanalyse internationaler Hopfenwirtschaft - Entwicklung des Simulationmodells für die technologisch-ökonomische Analyse auf Hopfenanbaugebieten in Slowenien. Verlag Dr. Kovac, Hamburg.

Pažek, K., Rozman, Č., Borec, A., Turk, J., Majkovič, D., Bavec, M., \& Bavec, F. (2006). The use of multi criteria models for decision support on organic farms. Biological Agriculture \& Horticulture, 24(1), pp.73-89.

Pintar, M. (2003). Osnove namakanja s poudarkom na vrtinah in sadnih vrstah $v$ severovzhodni Sloveniji, Ljubljana, Ministrstvo za kmetijstvo gozdarstvo in prehrano. pp. 21-35.

Recio, B., Rubio, F., \& Criado, J. A. (2003). A decision support system for farm planning using Agrisupport II. Decision Support Systems, 36, pp.189-203.

Romera, A. J., Moriss, S. T., Hodgson, J., Stirling, W. D., \& Woodward, S. J. R. (2003). A model for simulating rule-based management of cow-calf system. Computers and Electronics in Agriculture, 42, pp.67-86.

Rozman, Č., Tojnko, S., Turk, J., Par, V., \& Pavlovič, M. (2002). Die Anwendung eines Computersimulationsmodells zur Optimierung der Erweiterung einer Apfelplantage unter den Bedingungen der Republik Slowenien. Berichte über Landwirtschaft, 80(4), pp.632-642.

\section{Copyright Disclaimer}

Copyright reserved by the author(s).

This article is an open-access article distributed under the terms and conditions of the Creative Commons Attribution license (http://creativecommons.org/licenses/by/3.0/). 